\title{
ICT as Blending Methodology: A Case Study in a Bilingual School in Castilla la Mancha
}

\author{
Rafael Cruz González \\ University of Castilla-La Mancha, Calle Altagracia, 50, 13001 Ciudad Real, Spain \\ Rafael.Cruz@uclm.es
}

\section{ARTICLE INFORMATION}

Received: November 30, 2019

Revised: July 09, 2020

Accepted: July 15, 2020

Published Online: October 15, 2020

Keywords:

Blended Learning, Flipped Classroom, CLIL, Online Learning, ITC

\begin{abstract}
The use of Information and Communication Technologies (ICT) is increasingly affecting every aspect of our daily lives, including the educational field where new approaches and methodologies are being developed. CLIL is currently one of the most popular educational approaches in Europe as it combines specifically created online course materials with more traditional teaching strategies. The case study introduced in this paper involves a charter school in Castilla-La Mancha called La Merced where CLIL was introduced in 2013. In the academic year 2018-2019, the school was taken over by an international educational network named Red Educativa Arenales, which decided to modernize the school by introducing highly innovative education teaching strategies related to ICT methodology. The initial stage of the modernization plan consists of equipping every classroom with digital devices such as laptops and tablets, as physical textbooks have been substituted by an online learning platform. Most school stakeholders agree that this first year has proved to be highly satisfactory regarding students' motivation and academic achievement. Drawing on my experience as an English teacher in La Merced since 2011, in this paper I compare the classroom atmosphere and the academic achievements of my students until 2018, when more traditional methods were in use, to last year's textbook-free pilot program. I will focus on my own grade, namely 3rd level of secondary education class (age 15-16) whose exam results have remarkably improved since the implementation of ICT blending methodology.
\end{abstract}

\section{Introduction}

Technology permeates every aspect of our lives, affecting the way we interact with each other in both our professional and personal lives. In recent decades, the pace of technological change has sped up, with the current generation having grown up in a globalized and highly-interconnected world. Education has not been immune to these changes, but it faces the challenge of providing knowledge to children in a modern manner whilst also achieving the goals of an old-fashioned syllabus. In this sense, Education seeks effective methodologies to provide effective training and mastery on information technology for the next generation to help them be successful in a modern, information society. CLIL methodology is one popular method used in Europe facilitating the evolution of education to adapt to new behavioral social patterns.

Information and communication technologies (ICT) allow for relatively easy access to knowledge in a variety of areas outside of educational institutions
(Castells, 2006; Martín-Barbero, 2002). When applied to education, ICT technology constitutes a powerful tool when combined with traditional methodologies (traditional learning). Exclusive reading or participation in forums means that very few people can develop such skills such as negotiation techniques or leadership proficiencies (Aguado et al., 2011); however, traditional methodologies overemphasis the teacher's role as the source of all knowledge within the learning process.

The evolution of educational systems has contributed to the symbiosis of both these methodologies. As a result, bLearning (Blended Learning) modalities allow for the combination of online methods with face-to-face learning which boosts the development of target competencies. As described by Turpo (2012, p.129), "in operational terms, bLearning includes online activities in both its instructional design and in its face-to-face activities both of which are structured pedagogically such that 
competencies/objectives are achieved". The virtual environment, flipped classroom, blended learning, etc., are concepts which are becoming more and more used since the direction of education goes along society, evolving parallelly.

This paper will therefore deal with the initial stage of methodological blended learning from a previous starting point with the application of CLIL (Content and Language Integrated Learning). This is a leap from traditional learning and tools in which the teacher is the main provider of knowledge to a stage in which the student takes control of his own learning process and become more autonomous. The transition from a traditional learning environment to a web-based and digitized one has made a seemingly difficult task been eased through using CLIL and the innate skills of the millennial generations. The competence of the students and their ability to discriminate and acquire knowledge will be determined by their results from a motivational point of view.

The use of ICT has been promoted in the region of Castilla-La Mancha, Spain, in recent decades in order to develop the digital competence of students. Specific classrooms were fully equipped to provide every learning center with the necessary technology; however, due to the obsolescence of the equipment and the rapid evolution of technology, such an approach is unsustainable in the future. For that reason, ICT implementation has seen traditional printed textbooks substituted for digital materials, devices and virtual earning environments. This is called a digital "backpack", thereby embedding all the different subjects of every course.

Language learning (L2) through the use of ICT resources will be focused on in this paper and its subsequent benefits and drawbacks. In addition, the rise of linguistic programs has enabled the increased implementation of intercurricular activities, thereby enhancing the linguistic competence among students. As a result of this, there is an increasing tendency for both public and private schools to utilize these programs so they can offer a more appealing and high-quality educational experience, as well providing students with the potential of having a more successful future. Nevertheless, the methodology has some discrepancies and controversies when applied (these issues will in turn be analyzed later in this article.
The case study developed in this paper involves a semi-private bilingual School in Castilla-La Mancha called La Merced, where CLIL was introduced in 2013. The use of English in some subjects (such as Natural Science), has required a great effort from both the teacher and the student in certain classroom settings. In the academic year 2018-2019, the school was taken over by an international educational network named Red Educativa Arenales, which decided to modernize the school by introducing highly innovative education teaching strategies related to ICT methodology. Personalized education is one of the aims of this organization, as well as the search for academic excellence. Thus, the objective is to enable students with the capability of adjusting to a variable environment using innovative strategies such us Think-Based Learning (TBL), Project-Based Learning (PBL), Flipped Classroom, Cooperative Learning, etc. These strategies form a perfect melting pot to enhance bilingual projects and the acquisition of a second language.

\section{The Evolution Towards Blended Learning}

Traditional learning seems obsolete in the 21st century; as a result, researchers have been looking for more effective learning processes which enable students to acquire knowledge in a more relevant way: "The profile of our learners has changed. They are digital natives weaned on video games and Web 2.0 and have been described as "marching through our schools, carrying a transformational change in their pockets in the form of powerful multimedia handheld devices." (Chen, 2010). Schools are supposed to encourage students to do their best, to enhance their opportunities through acquiring relevant skills and knowledge, and to encourage students to be independent thinkers and autonomous individuals in order to succeed. According to these premises, the actual system does not fit their needs, since the teacher is still the source of knowledge - the teacher has the power of wisdom while students receive information in a mostly passive way. Thus, the deficiencies of the system lead to school failure and abandonment.

In a global world, quality of education is a major concern - this partly explains the ICT boom in this field, in particular in the area of language learning. Due to its status as a global language in many fields 
and subjects, the exposure to English is constant due to the creation of new concepts and coined expressions. As such, every language must adapt to it, yet the time of contact is not a vital variable to become proficient. Compared to traditional methodologies based on the teacher as the primary source of knowledge, printed materials, and the passive acquisition of knowledge via classroom lectures, the incorporation of ICT to education serves as a modern motivating tool. 'Winning' students and maintaining reputations in an ever-changing education 'market' is yet another new era for tertiary institutions (Rowley, 2006). Educators play a major role in the formation of students' personal identities by stimulating their development into active members of society (Willemse et al., 2005)

Electronic Learning and Mobile Learning were developed to fulfill expectations of this new era; nevertheless, in some context they may not be the right choice. Including some features of these methodologies in the learning and teaching process (Web-based technology) is a new popular trend in the education sector complementing traditional education through CLIL methodologies and technology affecting student's motivation in a positive way. Blended Learning is normally defined as the integration of traditional classroom methods with online activities (termed "e-Learning) (Macdonald \& Scandrett, 2008). Blended learning courses are becoming increasingly significant, with ICTs being developed to complement, not replace, traditional forms of learning (Mitchell \& Forrer, 2010). Blended learning is not simply integrating ICTs with the Face To Face approach (FTF-approach) (De George-Walker \& Keeffe, 2010). Furthermore, Blended learning represents a fundamental reconceptualization and reorganization of the teaching and learning dynamic, incorporating various learning elements such as online and traditional classroom environments, media for learning content delivery, synchronous and asynchronous interactions, different kinds of resources, as well as group and individual learning activities (Garrison \& Kanuka, 2004).

\section{Methodology}

The qualitative study carried shows the evolution from traditional learning to an initial stage of blending learning methodology.

\subsection{Features and Localization of the Education Center}

Located in Miguelturra and founded in 1944, the school started its project as a private institution, evolving to a full time educational center becoming member of two bilingual programs to improve English in school: BEDA program and Secciones Bilingües program (Department of Education of the regional government). Based on a more traditional education, CLIL methodologies started being used from that moment in initial stages of Primary Education especially even though technology does not always go hand in hand with this type of education for several reasons. During the academic year 20182019, the school started using Blended Learning with the utilization of a web-based platform changing the scope of the educational framework. Competencies, skills, knowledge and emotional aptitudes are assessed through a problem-based learning $(\mathrm{PBL})$, collaborative learning, continuous assessment and individualization of learning. This is directly reflected in the main role of the teacher who is not the main source of information: "the information-transmission component of a traditional face-to-face lecture is moved out of class time [... and replaced with] active, collaborative tasks." Consequently, students prepare for class by outsideclass activities normally covered by traditional lectures, thus freeing up valuable in-class time to studentcentered learning activities. After class, students can continue working on in-class tasks they did not finish, explore some topics in more detail, revise material, and further consolidate knowledge (Abeysekera \& Dawson, 2015). In the Flipping classroom (a student centered strategy in which a blended methodology is used in order to engage the student in their learning process in an active education) and according to Biggs (2011), the teacher must create a learning environment that facilitates learning activities that in turn make the students achieve the desired learning outcomes.

\subsection{Description of the Case Study}

This case study is presented as a piece of qualitative research analyzing the possible benefits and drawbacks with the integration of ICT in second language acquisition: "A mixture of teaching and learning methods will always be the most efficient manner in which to support student learning because only then 
it is possible to embrace all the activities of discussion, interaction, adaptation and reflection, which are essential for academic learning" (Towndrow \& Cheers, 2003). Al-Saleem et al. (2010) in his study investigated the effect of using blended learning on teaching English as a foreign language (EFL) on students' oral skills. The target group is the third course of Secondary Education (14 to 16 years old), a total of 24 students, and focusing on English as a subject.

The platform chosen for the current academic year is called AulaPlaneta, from Planeta Editorial; the platform contains every subject and an efficient environment to hold every aspect of the learning process in a safe space. The most remarkable features of the platform used during the school year; gives response to the adaptation to learning, instant results, diagnose tools, attention to students' diversity and critical thinking. The benefits of this platform are based on a non-situational background, that is, it can be worked on anywhere, not restricted to a device or classroom.

The structure of the units is logical, sequenced and structured according to the content established by law (Real Decreto 1105/2014, de 26 de diciembre) in which objectives, contents and resources are offered in a sequential and organized way fulfilling student's needs. One of the important features of this webbased platform is its capability of modification, that is, the teacher can add or even subtract any kind of information provided, or reorder contents if necessary. Every unit holds sequenced digital resources helping the teaching-learning process pedagogically; hence, the contents can be expanded or reduced regarding the student's needs. The general structure of each unit is as follows:

- Motivational situations to promote learning

- Acquaintance and comprehension of the subject

- Analysis and synthesis

- Revision and consolidation

- Structure acquired knowledge

- Self-assessment

The different resources suggested on the platform vary but allow for individual and collaborative learning via:

- Open questions and autocorrected activities (WebQuests)

- Debatable questions

- Interactive and audiovisual activities

\section{- Sequenced images}

- Texts regarding civilization, interesting facts and realia

Nevertheless, other materials are used in order to enhance the learning process and promote the use of actual trends of technology. These include, Kahoot, vidcasts and podcasts produced by students, YouTube videos, TV series, and so on, therefore enabling discussion among students. The flipped classroom is suitable to motivate self-learning of the topic and the discussion carried and guided by the teacher. Lectures are not used as the main source since the autonomy of student is the main target of this type of strategy. As J. Strayer (Strayer, 2007) defines, it is an "innovative classroom structure that moves the lecture outside the classroom via technology and moves homework and practice with concepts inside the classroom via learning activities".

\subsection{Research Design and Data Collection Process}

Previously, the students had always studied in a traditional background and methodology even though their digital skills were, in most cases, advanced due to their native skills. The change to blended learning therefore provided an opportunity to analyze its impact in a classroom of students exposed to it for the first time. Students were exposed to a fully integrated technological environment and new structures (flipped classroom).

The research was conducted through questionnaires, interviews and observation. Students filled the questionnaire provided within a reasonable amount of time regarding their satisfaction, motivations and academic results. The interviews were taken at the end of the academic year in order to measure the level of satisfaction with the overall course and their language assimilation. The data gathered was completed in terms of assessment, experiences and insights taken during the year and compiled to show some results.

\section{Discussion of the Results}

The study used a method of gathering personal data, views, comments and questions from the target group. It has been possible to acknowledge the different methodologies used so far: Traditional learning and 
blended learning. The personal data from all the participants of the target group includes gender (12 girls and 12 boys), age (from 14 to 16 years old), motivation towards English, motivation towards technology, resilience to change and training. The results of the questionnaire are detailed in the table below:

\section{Do you feel motivated towards learning English using this methodology?

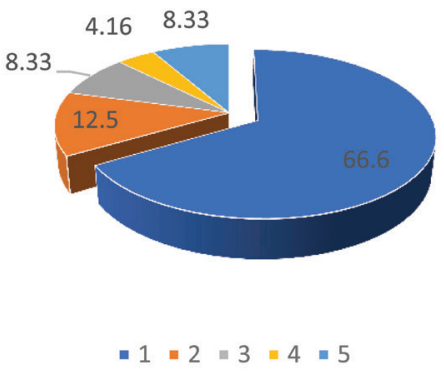

Figure 1: Motivation towards the utilization of blended methodology.

\section{How hard did you find the change of methodology?}

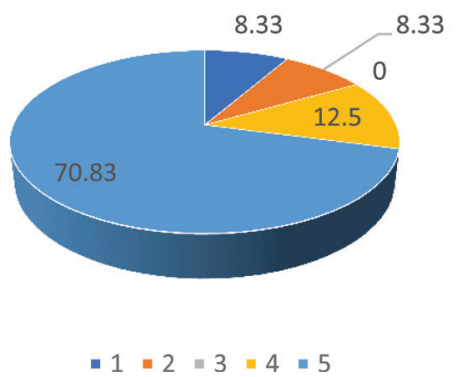

Figure 2: Adaptation to the methodology.

To the question "how comfortable do you feel with technology?", the percentage of positiveness was almost unanimous: $90 \%$ of students declared being comfortable using it. Nevertheless, the outcome of the following question was rather surprising due to the answers to the previous question: "how comfortable do you feel using laptops in class?". The percentage of those comfortable in this question lowered to $70 \%$ according to two different variables. This was due to the lack of prior training with laptops. The erroneous assumption of the target group being a digital native reveals that this generation is not fully ICT native but, rather, are mostly digitally native with handheld devices; thus, every student who owns a mobile phone is a "mobile digital native" rather than just a digital learner.

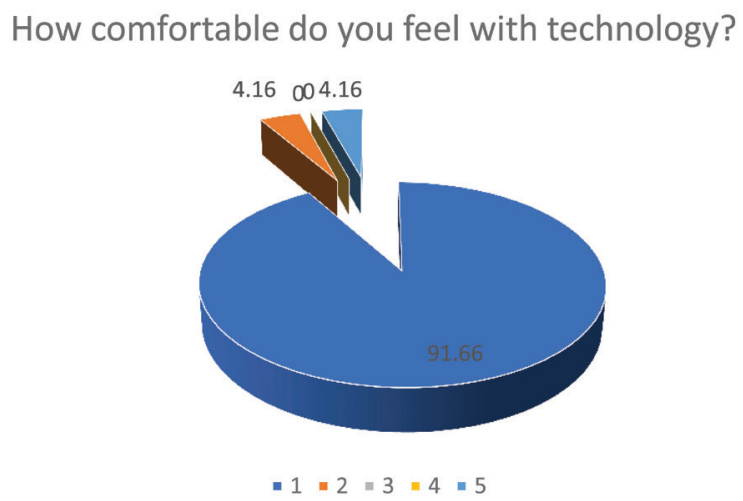

Figure 3: Adaptation and feelings towards a technological environment.

how comfortable do you feel using laptops in class?

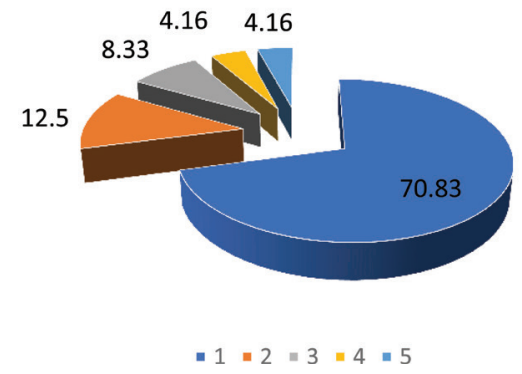

Figure 4: Adaptation to digital textbooks.

The second factor is resilience to change. In this case study, the educational system of the target group had up to the academic year 2018-2019 followed a traditional methodology. It emerged over the course of the year that a traditional methodology was still preferred by a significant proportion of students, since 25 per cent of respondents printed all the materials for study and 50 per cent printed part of the syllabus. It suggests that the idea of a teacher-centered method involving faceto-face interaction dependent on students knowing the content of their textbooks and notes is still preferred by a significant proportion of students (Dimitrios, Labros, Nikolaos, Maria \& Athanasios, 2013; Wei Li, 2016).

The main complaint about this blending methodology is the use of laptops since students are not fully digitally native, and they therefore become frustrated and stressed when the device is not working. Also, parents (who were generally not technologically 
native) lacked control over the children's work and were unable to effectively assist them at points. On the other hand, students' motivation was satisfactory due to the immediate results (competitiveness), but the deadline of assignments was a controversial issue due tosome students feeling micromanaged.

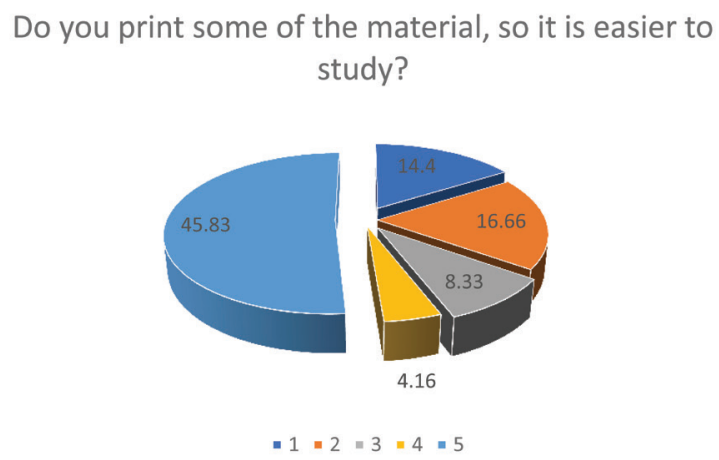

Figure 5: Resilience to the change.

Do you print all the material, so it is easier to study?

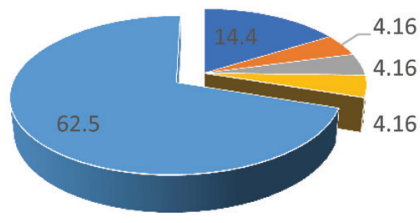

- $1=2=3=4=5$

Figure 6: Problems with the adaptation to the new methodology.

Not all the activities proposed were universally supported, especially those regarding language production such as videos and podcasts. The main factor for students not engaging with these activities was due shyness or lack of self-esteem, and they therefore felt embarrassed recording themselves either individually or collaboratively. Other collaborative oral activities were avoided by students for similar reasons. Other Individual or collective activities such as Kahoot were highly motivating as they added a friendly competitive factor into their learning.

Regarding their overall satisfaction, the results were quite positive, whilst it is also important to note the initial stress suffered while adjusting to the new environment and learning approach. At the end of the course, students had become acquainted with the methodology and the learning process very positively according to their results. Additionally, if English is taught within the blended learning approach, the result is positive learning outcomes (that is, high academic performance, good critical/thinking skills, etc). (Almasaeid, 2014; Fakhir, 2015; Slomanson, 2014).

Rate your satisfaction with other online activities (Live worksheets, Kahoot!, etcetera)

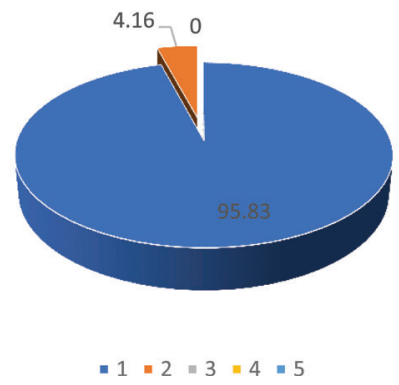

Figure 7: Student satisfaction with the non-traditional material.

\section{What is your overall satisfaction?}

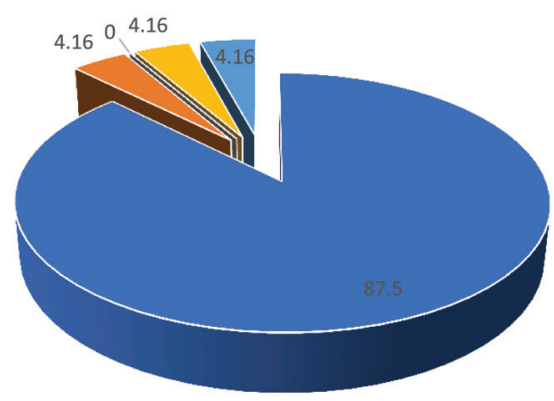

- $1=2=3=4=5$

Figure 8: Overall satisfaction of students.

\section{Conclusion}

This case study analyzed the change of learning methodology as for the enhancement of English language skills within a selected group of secondary students in a school in Castilla-La Mancha, Spain, with English as a foreign Language (EFL) as the scope of study of the effects of traditional and blended learning. Despite the initial problems regarding technology and lack of skills even with the digital skills of students, the level of satisfaction was quite high in terms of results and motivation. The stress caused by the change in methods and activities related to producing language amongst shy or unconfident individuals were the main 
obstacles in successfully implementing more ICT resources in the classroom. However, confident or selfassured students successfully adopted the new methods with enthusiasm. Thus, there are both positive and negative results in terms of willingness, satisfaction and stress in regard to ICT methodologies. Motivation is a key factor and the student must feel as if they were in natural speaking environment. High rates of adoption and integration of digital technologies, pedagogies and in-class methods of teaching and learning have also been reported to increase student motivation to learn in newly innovated digital technologies environments. (cf. blended learning environmentBLE) (Machumu, Zhu \& Sesabo, 2016; Ocak \& Akçayır 2013; Radosavlevikj, 2016). In this direction, other researchers have studied similar effects and its impact on new methodological processes of education (Eryilmaz, 2015; Graham \& Dziuban, 2015)

According to these last trends in education and the extensive use of technology in every aspect of society, education cannot be left behind evolution and it must adapt itself. This type of methodology has arrived in order to permanently stay to complete, enhance and maximize the results of the educative process.

\section{References}

Abeysekera, L., \& Dawson, P. (2015). Motivation and cognitive load in the flipped classroom: definition, rationale and a call for research. Higher Education Research \& Development, 34(1). pp. 1-14. https://doi.org/10.1080/07294360.2014.934336

Aguado-Franco, J.C., Matosas-Lopez, L., \& GómezGalan, J. (2019). Constructing an instrument with behavioral scales to assess teaching quality in blended learning modalities. Journal of New Approaches in Educational Research, 8(2), 142-165. https://doi.org/10.7821/naer.2019.7.410

Akbarov, A., Gönen, K., \& Aydoğan, H. (2018). Students' Attitudes Toward Blended Learning in EFL Context. Acta Didactica Napocensia 11(1), 61-68. https://doi.org/10.24193/adn.11.1.5

Almasaeid, T. F. (2014). The effect of using Blended Learning Strategy on achievement and attitudes in teaching science among $9^{\text {th }}$ grade students. European Scientific Journal, 10(31), 133-145. https://doi.org/10.19044/esj.2014.v10n31p\%p

Al-Saleem, B.I., Samadi, O.M., \& Tawalbeh, M.A. (2010). The effect of using blended learning on EFL Jordanian tenth grades student's oral skills (pp. 99-128). Proceedings of Education in the Era of Alternatives Conference. Yarmook University, Jordan, 20-22 April.

Biggs, J., \& Tang, C. (2011). Teaching for Quality Learning at University. McGraw Hill/Open University Press, $4^{\text {th }}$ edition.

Bonk, C.J., \& Graham, C. R. (2005). (Eds.), Blended Learning Systems: Definition, Current Trends, and Future Directions. Handbook of Blended Learning: Global Perspectives. San Francisco, CA: Pfeiffer Publishing, pp. 3-21.

Castells, M. (2006). La revolución de la tecnología de la información. In M. Castells (Ed.), La era de la información: economía, sociedad y cultura (pp. 55-92). México: Siglo XXI Editores.

Chen, M. (2010). The Youth Edge: Digital Learners Carrying Change in Their Pockets. In Education Nation: Six Leading Edges of Innovation in our Schools (pp. 213). San Francisco: Jossie-Bass.

Council of Europe (2001). Common European framework of reference for languages: Learning, teaching, assessment. Cambridge: Cambridge University Press.

De George-Walker, L., \& Keefe, M. (2010). Self-determined blended learning: a casestudy ofblended learning design. Higher Education Research \& Development, 29(1), 1-13. https://doi.org/10.1080/07294360903277380

Deller, S. (2005). Teaching other subjects in English (CLIL). In English!, Spring 2005, pp. 29-31.

Dimitrios, B., Labros, S., Nikolaos, K., Maria, K., \& Athanasios, K. (2013). Traditional teaching methods Vs. Teaching through the application of information and communication technologies in the accounting field: Quo Vadis? European Scientific Journal, 9(28), 73101. https://doi.org/10.19044/esj.2013.v9n28p\%p

Dziuban, C.D., Hartman, J.L., \& Moskal, P.D. (2004). Blended learning. EDUCAUSE Center for Applied Research Bulletin, 7, 112.

Eryilmaz, M. (2015). The Effectiveness of Blended Learning Environments. Contemporary Issues in Education Research (CIER), 8(4), 251-256. https://doi.org/10.19030/cier.v8i4.9433

Fakhir, O.M. (2014). The effect of dissect strategy on first year EFL university students' word awareness. European Scientific Journal, ESJ, 10(14), 399-419.

Friesen, Norm (2012). Report: Defining Blended Learning. Retrieved from https://www.normfriesen.info/papers/ Defining_Blended_Learning_NF.pdf

Garrison, D.R. \& Kanuka, H. (2004). Blended learning: Uncovering its transformative potential in higher 
education. Internet \& Higher Education, 7(2), 95-105. https://doi.org/10.1016/j.iheduc.2004.02.001

Graham, C.R. (2005). Blended learning systems: definition, current trends, and future definitions. In C. J. Bonk \& C.R. Graham (Eds.), Handbook of blended learning: Global perspectives, local design. (pp. 3-21). San Francisco, CA: Pfeiffer Publishing.

Graham, C.R., \& Dziuban, C. (2007). Blended Learning Environments. Handbook of Research on Educational Communications and Technology: A Project of the Association for Educational Communications and Technology. 2.

http://www.educa.jccm.es/es/sistema-educativo/ decretos-curriculo/normativa-vigente-educacionsecundaria-obligatoria.ficheros/194269BOE-A-2015-37.pdf

Koc, S., Liu, X., \& Wachira, P. (2015). Assessment in Online and Blended Learning Environments. America: Age Publishing Inc 2015.

Macdonald, J., \& Scandrett, E. (2008). Blended Learning and Online Tutoring: Planning Learner Support and Activity Design. Hampshire, UK: Gower 2008.

MacHumu, H.J., Zhu, C., \& Sesabo, J. (2016). Blended Learning in the Vocational Education and Training System in Tanzania: Understanding Vocational Educators' Perceptions. International Journal of Multicultural and Multireligious Understanding, 3(2), 30-45.

Martín-Barbero, J. (2002). The crisis of the professions in the "knowledge society". Nómadas, 16, 177-191.

Mitchell, P., \& Forer, P. (2010). Blended learning: The perceptions of first-year geography students. Journal of Geography in Higher Education, 34(1), 77-89.

https://doi.org/10.1080/03098260902982484

Ocak, M.A., \& Akçayır, M. (2013). Do motivation tactics work in blended learning environments?: The ARCS model approach. International Journal of Social Sciences \& Education, 3(4), 1058-1070.

Radosavlevikj, N. (2017). Creating new opportunities for Language Learners: "Blended Learning Solution" (A case study implemented with mixed ability students in the Language Centre, SEEU-Skopje). New Trends and Issues Proceedings on Humanities and Social Sciences, 3(5), 63-80.

https://doi.org/10.18844/prosoc.v3i5.2006

Rowley, J. (2006). What is quality teacher education for music education students? Proceedings of the $3^{\text {rd }}$ International Conference on Teaching and Learning in Higher Education: TLHE Centre for Development of Teaching and Learning (CDTL), National University of Singapore, Singapore December 2006, pp. 228-230.

Slomanson, W.R. (2014). Blended Learning: A Flipped Classroom Experiment. Journal of Legal Education, 64(1), 93.

Stein, J., \& Graham, C.R. (2014). Essentials for Blended Learning: A Standards-Based Guide. New York: Routledge.

Strayer, J. (2007). The effects of the classroom flip on the learning environment: A comparison of learning activities in a traditional classroom and a flip classroom that used an intelligent tutoring system (Dissertation). Ohio State University.

Towndrow, P., \& Cheers, C. (2003). Learning to communicate effectively in English through blended e-learning. Teaching and Learning, 24(1), 55-66.

Turpo, O. (2012). La modalidad educativa Blended Learning en las universidades de Iberoamérica: Análisis y perspectivas de desarrollo. Educar, 48(1), 123-147.

Wei Li, Y. (2016). Transforming Conventional Teaching Classroom to Learner-Centred Teaching Classroom Using Multimedia-Mediated Learning Module. International Journal of Information and Education Technology, 6(2), 105-112. https://doi.org/10.7763/IJIET.2016.V6.667

Willemse, M., Lunenberg, M., \& Korthagen, F. (2005). Values in education: A challenge for teacher educators. Teaching and Teacher Education, 21(2), 205-217. https://doi.org/10.1016/j.tate.2004.12.009 


\section{Issues and Ideas in Education}

Chitkara University, Saraswati Kendra, SCO 160-161, Sector 9-C, Chandigarh, 160009, India

Volume 8, Issue 1

March 2020

ISSN 2320-7655

Copyright: [C 2020 Rafael Cruz González] This is an Open Access article published in Issues and Ideas in Education (Issues Ideas Educ.) by Chitkara University Publications. It is published with a Creative Commons Attribution- CC-BY 4.0 International License. This license permits unrestricted use, distribution, and reproduction in any medium, provided the original author and source are credited. 